Copyright (C) 2021 The Author/s

This work is licensed under a CC-BY 3.0 License

Peer review method: Double-Blind

Accepted: September 13, 2021

Published: September 21, 2021

Original scientific article

DOI: https://doi.org/10.47305/JLIA2137140a

\title{
HOW GOVERNMENT OUTFLOW AND PUBLIC DEBT AFFECT INFLATION: EVIDENCE FROM SEE COUNTRIES
}

\author{
Erëza A. Arifi \\ College for International Management - Prishtina, Kosovo \\ ORCID iD: https://orcid.org/0000-0001-5197-1606 \\ ereza.arifi@kolegjiglobus.com
}

\begin{abstract}
The study aims to address public debt and government outflow affecting inflation in some of the countries of Southeast Europe, observing a combination of factors both theoretically and econometrically. The investigation included six (6) SEE countries, including the 2006-2020 timeframe, with 90 observations. The dynamic approach, the fixed effect, and the Arellano/Bond estimator were used to check the parameters considered in the study using panel data. Furthermore, the study also applied diagnostic tests such as the Sargan over-identifying restrictions and Pedroni test for cointegration. The results of the fixed effect and Arellano / Bond estimation demonstrate that public debt, current budget outflows, and capital budget outflows affect inflation, while overall budget outflows are insignificant. For further studies, it would be useful to apply other dynamic models by applying other specific factors, which will be considered as a useful contribution to the academic, research, and policymaking structures.
\end{abstract}

Keywords: Public Debt; Government Outflows; Panel Data; Fixed-Effect

\section{INTRODUCTION}

The dynamics of inflation control are essential to the intention of monetary and fiscal policy. In recent decades the nexus between public debt and inflation, since public debt plays an important role in funding fiscal deficits, has arisen as a related area. Governments began to investigate if increasing levels of public debt affect inflation. Inflation pointing strategy was established by several central banks mainly because inflation is typically a monetary phenomenon. Nevertheless, several recent studies have deemed it outdated or unfounded. According to Sims (2016), persistent and growing fiscal deficit finance through government borrowings will eventually produce inflationary burdens, regardless of the policies followed by the Central Bank. Deficits supported by debt will thus require efficient coordination with the monetary authority to avoid excessive and volatile rates of inflation that may damage macroeconomic stability. 
Moreover, according to Aimola and Odhiambo (2018), monetarist policy's effectiveness in controlling inflation depends critically on its coordination with tax guidelines, which advocates that the grant of central bank autonomy may not be successful to curb inflation in the hope of isolating an economy from the need to accomplish imprudent tax guidelines. As incorporated in Non-Ricardian policy, the Fiscal Concept of Price Level (FTPL) argues that financial authorities themselves can dominate inflation independently of monetary policy. Government capital outflows play an important role in long-term economic development and living standards, while at the same time trying to keep inflation under control. Due to undervaluation in consumption and/or non-exclusivity in use, private companies will tend to under-provide the main types of investment outflows. Therefore, there is a role for the government to increase social welfare by providing capital outflows, even after it has to tax private resources to finance it. Economic history is replete with examples of capital investment, and infrastructure, in particular, which have had significant impacts on long-term GDP and/or welfare. For instance, Gordon (2017) points out that publicly invested capital contributions to clean water structure, electrical structure have had an influence on equally life expectancy and productivity growth in the US during the first half of the XX century. More recently, government infrastructure outflows have also figured prominently in policy discussions regarding short-run stimulus.

Government infrastructure outflows are viewed by many policymakers as having advantages over government consumption outflows for stimulating the economy during a recession. In traditional Keynesian philosophies, both productive and wasteful government spending stimulate the economy in the short run through standard income and multiplier effects and help push output back to potential output. Government investment outflows such as infrastructure spending, nevertheless, have the additional advantage that it can change the path of potential output. In particular, if a short-run increase in government outflows also raises the stock of productive public capital or long-run total factor productivity (TFP), then government spending provides two benefits: Keynesian demand stimulus in the short run and neo-classical supply stimulus in the long run. These lasting effects are particularly welcome since typically stimulus packages must be financed with an increase in distortionary taxes after the recession is over. If output remains higher because of the long-run effects of more public capital, then the tax base expands and the required increases in tax rates are less.

The motive for examining these SEE nations is because they have nearly the same attitude and mentality in terms of ideology as the policymakers and aspire to be part of the EU family. The study, therefore, focuses on determining macroeconomic drivers of how they impact inflation, based on the previously mentioned concerns. To accomplish the objective, we have posed the question of research:

RQ: Do public debt and government outflows affect inflation for the countries selected in the analysis? 
Moreover, the dynamic approach with the panel data, employing fixed-effect regression and Arellano-Bond econometric estimation as well as certain assessments for model steadiness, is used to the research question. The research is based on several points of view, firstly on contributing to the progress of the literature to researchers and policy structures, secondly, on the use of the latest data and drawing conclusions based on the econometric approach, with an original scientific contribution which finally points to the possible policy implications for SEE economies. Research in the defined method consists of the reasonable structure and processing flow starting from the first segment with an introduction, the second segment discusses the aspects of the review of the theoretical and empirical literature, the third explores the methodology, the description of the empirical approach, section four findings discussion and the last segment conclusions.

\section{THEORETICAL BACKGROUND}

\section{Theoretical Literature Review}

Theoretically, the most widely accepted school of thought on inflation is that it is a macroeconomic issue and its control is within the purview of the regulatory authorities. Inflation is a macroeconomic phenomenon, according to Friedman (1968). An expansionary regulatory policy will in the near term raise both real output and general price levels, with only the price level increasing in the long term (Friedman, 1968). The monetarist pricing theory is based on the notion that the currency has absolute influence over prices. Active regulatory policy and passive fiscal policies operate within a framework that establishes the Ricardian theory (Erdogdu, 2002).

There are, nevertheless, two opposing views on the interaction between regulatory and fiscal policies and their effects on price constancy. The classical view of Ricardians argues that it is the demand for liquidity and its progress over time that defines the path of prices (Attiya et al. 2008). In such a rule, fiscal policy is passive, suggesting that government bonds are not net wealth, and financial policy works through interest rates to determine prices. The Ricardian view assumes that price levels are mainly determined by money supply in the long run (Attiya et al. 2008).

The Ricardian equivalence, according to Barro $(1974 ; 1989)$ is based on a monetarist view on inflation that budget deficit or public debt does not have a significant influence on the determination of price level, implying that government bonds are not net wealth. He argues that household wealth is effectively reduced because of the existence of uncertainty concerning individual future tax liabilities, suggesting that public debt may increase the overall risk contained in household balance sheets. 
The consequences of this strategy from an inflation point of view are clarified by non-Ricardial assumptions regarding price regulation. Based on the FTPL study carried out by Kwon et al. (2006) public debt was recognized as a highly relevant indicator that influences inflation. The opinion presumes that increased effects of public debt enhance the overall wealth of households and hence raise demand for goods and services, leading directly to price pressures. The connection between public debt and inflation might be direct or indirect (Nastansky and Strohe 2015).

On the other hand, research by Sims (2016) also suggests that public debt is inflation-caused since new securities are emitted to cover past debts if the government wishes to satisfy its commitments without raising taxes and emit new sums of money. This activity just results in transferring debt from one period to the next. In addition, measures such as expanding public debt have to be influential on inflation irrespective of the policies followed. Government outflow refers to money disbursed by any country's government in fulfilling its constitutional responsibility to provide citizens with community amenities and to defend its national integrity. Inflation, nevertheless, shows that the monetary prices of goods and services are continually increased, and inflation means that prices are rising (Blanchard, 2006). Government outflows, ceteris paribus, may be causally inflation-related. It would thus be vital to explore the nature and scope in SEE countries of any causal link (ceteris paribus).

Empirical Review and Development of Hypothesis

From the point of view of the econometric literature on public debt investigations, general government outflows, current government outflows, as well as investment capital outflows have been addressed by numerous researchers. The authors who have dealt with inflation in recent years are Amiola et al. (2021) analyzing Nigeria, Urquhart (2021) analyzing the economy of Portugal, Guei (2019) analyzing the emergent countries, France and Janssens (2018) have analyzed inflation in Africa. A large number of studies have been done by treating panel countries such as Kwon et al. (2006) has treated a sample of 71 countries, where 13 of them are considered very advanced economies, 10 other advanced economies, and 43 developing economies using data for 43 years. He argues that an increase in public debt is typically inflationary in developing countries, has a low association with other advanced economies, and has no influence on countries with highly developed economies. Moreover, other identical results achieved by Lopes Da Veiga et al. (2016) have concluded that there is a strong positive association in developing countries between these two indicators. Furthermore, Taghavi (2000), and Karakaplan (2009) have found that economies with developed financial markets, advanced economies, and developing countries that have low levels of public debt have been found to have a negative influence between public debt and inflation. From the context of analyzing macroeconomic determinants among public debt and 
inflation, the authors Kryeziu and Durguti (2019) using OLS and some other econometric approaches, concluded that there is a stable positive connection among these two indicators at the level of significance 1 percent of the Western Balkans countries. Whereas, the most recent study conducted by Durguti et al. (2020) where it is explicitly treated using the VECM technique and ADF unit root test, there is a strong positive association among budget deficit, government debt, exchange rate, and inflation both in the short run and in the long run. Therefore, based on the analyzed studies the study has developed the following hypothesis:

Ho: The increase in public debt has an important positive influence on inflation.

Ha: The increase in public debt has an important negative influence on inflation.

Some observed studies have been performed on the effect of government outflow on inflation and the theoretical also observed data demonstrates that extended fiscal expansions are contributing to inflation. Han and Mulligan (2008) carried out the study on three dimensions of data; cross-country data were analyzed for the association among inflation and size of government in long run for 80 states, whereas time series data were used to identify the changes in overall expenditure in disaggregate levels of defense and non-defense expenses. To rectify the possible endogeneity problems in size of the government and non-defense outflow, the government expenses on social security to outcome ratio was used. Accordingly, they found a confident strong association between inflation and the size of government during wartime. Furthermore, non-defense expenditure is negatively related to inflation and it is insignificant. Government outflows are handled or developed indirectly to a smaller extent than other macroeconomic factors. Nguyen (2019) studied Asian economies (India, China, and Indonesia) using the co-integration technique and VECM, covering the 1970-2010 period, the impact of government expenses on inflation.

The results of co-integration have proven that there is a causal connection between government expenses and long-term inflation, but, in the short run, this has a negative consequence on China's economy and a positive impact on India and Indonesia's economies. Hence, assumed that the findings argue contradictory marks, the hypothesis in our case is set out as follows:

Ho: The overall government outflow has an important positive influence on inflation.

Ha: The overall government outflow has an important negative influence on inflation. 
Current government outflows are under the other category of government outflows, which are largely meant for the execution of government operations for goods and services. Researchers in many countries have very slight consideration of current government expenditure. Attari and Javed (2013), employing the ARDL, Granger Causality, and Johansen Cointegration method of an advanced dynamic approach, concluded that this indicator is long-term correlated with inflation. On the other hand, (Egbetunde and Fasanya 2014) claim that overall expenses have a modest positive connection of the current public spending with inflation. The presented hypothesis is:

Ho: The current government outflow has an important positive influence on inflation.

Ha: The current government outflow has an important negative influence on inflation.

Lastly, in the context of government outflows, the most significant variable is capital investment. The authors that used the multifactorial regression analysis (Kryeziu and Durguti 2019) claimed that any capital expansion has an influence directly on inflation since this impact the production of extra money that is indirectly linked to consumption. Egbetunde and Fasanya (2014) have reached the same conclusion by investing in capital projects, such as road infrastructure, social issues, or other capital projects that have a direct impact on inflation. The hypothesis presented is:

Ho: The capital government outflow has an important positive influence on inflation.

Ha: The capital government outflow has an important negative influence on inflation.

The hypotheses and consequences will be evaluated in the last stage of the research via the applicable estimations.

\section{METHODOLOGY}

This segment includes the study's full procedure and approach, including statistics collection and explanation, model specifications, root unit tests, co-integration tests, the fixed effect, and the Arellano-Bonde GMM estimation.

Data Source

To carry out this study, we have used the secondary data extracted from the World Bank database in the format defined by the criteria of IFM and the World Bank. The data sample consists of 6 SEE countries (i.e., Albania, Bosnia and Herzegovina, Kosovo, North Macedonia, Montenegro, and Serbia). 
The data included in the investigation cover the period 2006 to 2020, which in total are 90 observations in 6 panels group. The applied data are strongly balanced and categorized into two groups, inflation as a dependent variable and the public debt, general government outflows, government current outflows, and capital outflows as explanatory variables. The selection of the econometric approach studies is based on the approach applied by Kwon et al. (2006), Nguyen (2015), and Romero and Marin (2017). Table 1, offerings classification, description, and expected results of each parameter in particular.

Table 1: Variable Descriptions and Expected Sign (Source: Own research)

\begin{tabular}{|l|l|l|l|l|}
\hline \multicolumn{1}{|c|}{ Variable } & \multicolumn{1}{|c|}{ Denominations } & \multicolumn{1}{c|}{ Acronyms } & \multicolumn{1}{c|}{ Sign } \\
\hline $\begin{array}{l}\text { Dependent } \\
\text { Variable }\end{array}$ & Inflation & INF & \\
\hline $\begin{array}{l}\text { Explanatory } \\
\text { Variables }\end{array}$ & Public debt & PD_gdp & $+/-$ \\
& Total budget outflows & TBO_gdp & + \\
& Current budget outflows & CBO_gdp & $+/-$ \\
& CBI_gdp & + \\
\hline
\end{tabular}

In Figure 1, the intermediate oscillation of the two parameters for the SEE countries is presented. The figure shows that their movement is almost constant between observations 35, where there is a more pronounced movement compared to other periods.

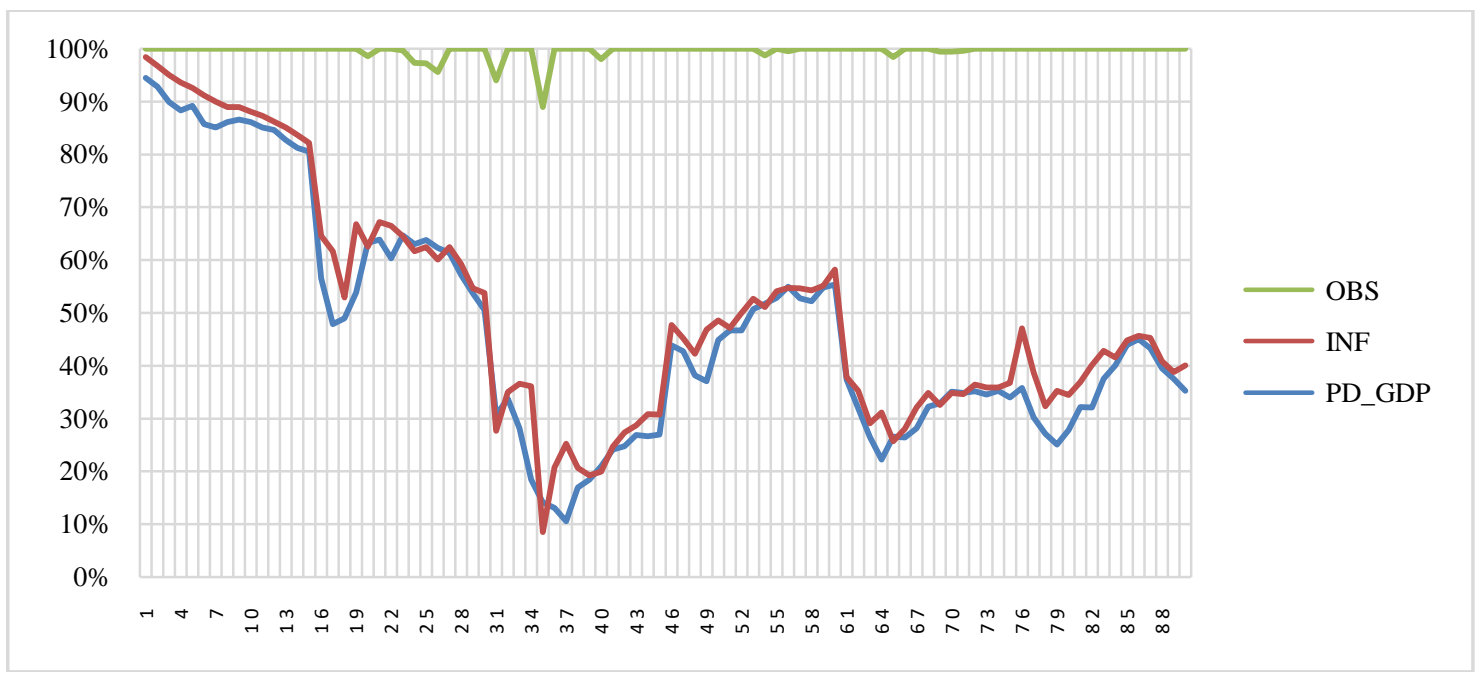

Figure 1: Public Debt and Inflation Trend during 2006-2020

(Source: World Banka Dataset and Author's calculation) 


\section{Estimation Approach}

Public debt and government outflows in the last decade have been the focus of many scholars in the international arena, not excluding interest in European countries by applying different approaches and models, or treating countries as individuals and in panel groups. Thus, the definition of the econometric model is based on recent studies conducted with the sole purpose of reaching more consistent arguments regarding the parameters selected in the analysis. The useful empirical approach is adapting the econometric model applied by Durguti et al. (2021) in their study evaluating macroeconomic determinants' effect on inflation for the Western Balkan countries. Also, as an additional reference on the applied methodology, the study is based on the study conducted by Romero and Marin (2017) analyzing the data of 52 countries through the combination of econometric approach as vector autoregression model, fixed effect, and Arellano-Bond estimation. The motive for selecting this approach is because the fixed effect of GMM estimation, in particular, gives consistent results when dealing with the data panel, and the number of observations is large. Therefore, based on the facts highlighted in this study, the dynamic approach is applied to assess the defined components and how they affect inflation. One of the advantages of the use of the data panel is that these two approaches allow the degree of individual heterogeneity which is not characterized during the use of time series (Batagli 2013).

In the following, we will give the formulas of the fixed effect and the GMM estimation on the premise of an explanation of the factors in this assessment and the specified method for the applied econometric research:

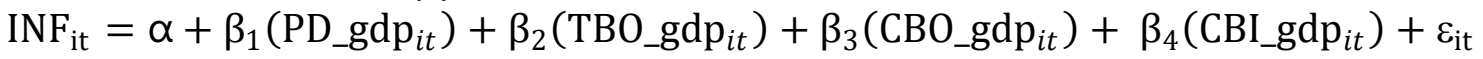

The formula according to the dynamic-GMM approach, applying the factors outlined within the $1^{\text {st }}$ difference is:

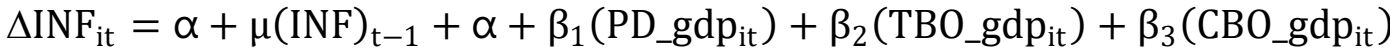

$$
\begin{aligned}
& +\beta_{4}\left(\text { CBI_gdp }_{\text {it }}\right)+\varepsilon_{\text {it }}
\end{aligned}
$$

Table 2 contains the fundamental details of all proposed inflation evaluation criteria.

Table 2: Summary Statistics (Author's Calculation)

\begin{tabular}{|l|c|c|c|c|c|c|}
\hline Variable Description & Obs & INF & PD_gdp & TBO_gdp & CBO_gdp & CBI_gdp \\
\hline Smallest & 90 & -2.40 & 5.20 & 19.10 & 14.60 & 1.60 \\
\hline Largest & 90 & 16.30 & 79.34 & 50.90 & 43.10 & 11.10 \\
\hline Mean & 90 & 2.82 & 41.76 & 35.97 & 31.33 & 4.82 \\
\hline Standard deviation & 90 & 3.25 & 19.53 & 7.61 & 8.43 & 2.29 \\
\hline Skewness & 90 & 1.59 & -.04 & -.02 & -.33 & .77 \\
\hline Kurtosis & 90 & 6.12 & 2.06 & 2.00 & 1.75 & 3.15 \\
\hline
\end{tabular}


The results produced in qualified to the inflation show that the mean constant among periods was with a coefficient of 2.82 , with a standard deviation of 3.25 . The smallest value has reached -2.4 this value achieved by Kosovo in 2010, while the largest has reached 16.3 value achieved by Serbia in 2006. Public debt or government debt -toGDP have variations with a standard deviation of 19.5 percent. The smallest value is 5.2 , reached in 2012 in Kosovo, while the largest value is 79.3 was reached in Montenegro in 2019. The indicator total government outflows in this study reached the smallest value in 2008 in Kosovo in the amount of 19.1, while the maximum value is 50.9 was reached in Bosnia and Herzegovina in 2009. The skewness value for this parameter is with the coefficient of -0.02 , while kurtosis is in value of 2.0. which has to do with the sources of the financing fund is noticed that there are oscillations within the euro-area countries with a standard deviation of 49.45. Current spending is assessed at the level of the local and central government expenditures on services and commodities with the lowest value maintained by the Government of Kosovo in 2008 at 14,6 percent of GDP while the government of Bosnia and Herzegovina attained a high value of 43,1 percent of GDP in 2010.

Regarding capital budget investment indicator reached a minimum value of 1.60 in Montenegro in 2017, and a maximum value of 11.1 was reached by Kosovo in 2012. The strategy and concept of governance in terms of capital investment are virtually the same, where all capital investments are geared towards infrastructure and the major road. Moreover, budget estimates beyond 2021 lead us along the same lines, where the Albania, Kosovo, and Serbia highways are expected to be completed and the European countries will continue to connect this section.

Table 3: Correlation Statistics (Source: Author's calculation)

\begin{tabular}{|l|c|c|c|c|c|}
\hline Variable Description & INF & PD_gdp & TBO_gdp & CBO_gdp & CBI_gdp \\
\hline INF & 1.000 & & & & \\
\hline PD_gdp & -0.084 & 1.000 & & & \\
\hline TBO_gdp & 0.183 & 0.318 & 1.000 & & \\
\hline CBO_gdp & 0.142 & 0.359 & 0.956 & 1.000 & \\
\hline CBI_gdp & -0.042 & -0.413 & -0.228 & -0.452 & 1.000 \\
\hline
\end{tabular}

Table 3 indicates the correlations among the variables applied to inflation, which is defined as the main indicator for measuring the impact of public debt and government outflows. In addition to the interconnectedness between the parameters, the results given in Table 3 indicate that the dataset used in the analysis hasn't any difficulty with multi-collinearity and may thus continue using additional analyses (Malhotra 2019). From the outputs, it is noticed that inflation has a low confident relationship with a coefficient of 0.183 or 18.3 percent with total budget outflows and 
0.142 or 14.2 percent with current budget outflows, while a low harmful association has the public debt and capital budget outflows with the inflation with a constant of -0.084 or 0.84 percent, respectively -0.042 or 0.42 percent. However other variables as seen from the association table show that they have a modest confident connection with inflation.

\section{RESULTS AND DISCUSSION}

Based on the outputs produced in this revision, it would primarily be necessary to analyze and discuss some applied assessments which determine the importance and appropriateness of the applied models. Thus, the F-test has a coefficient of 6.46 , with a probability of 0.001 which tells us that all the constants applied in the model have a value less than $P<10$, and based on this we can state that the parameters are suitable for a stable examination. Additional arguments that add value to the stability of the model is R-squared is in the value of 0.5465 , which means that the explanatory variables have an impact or describe the dependent variable at the level of 54.7 percent.

In addition, Durbin-Watson was used to evaluate the serial correlation of panel countries based on the 0 to 4 range. When the constant of information is between 0 and 1.5, the statistics have an adverse association, although the statistics have autocorrelation when the constant is between 1.5 and 2.5. if the constant is between 2.5 and 4, then the information has a high positive serial correlation (Durbin and Watson., 1971); (Racine and Hyndman., 2002). While in the evaluation of the second approach through GMM estimation we have applied the AR (1) test, where wald chi2 is in the value of 547.32 and that with a probability of 0.000 which indicates the adequacy of the applied approach. The findings obtained by the second GMM method for the predictor variables with 1 lag difference and one step are tested in the first difference. 
Table 4: Estimation Results (Source: Author's calculation)

\begin{tabular}{|c|c|c|c|c|}
\hline \multirow{3}{*}{ Variable } & \multicolumn{2}{|c|}{ Fixed Effects Regression Model } & \multicolumn{2}{|c|}{ GMM - Arellano-Bond Estimation } \\
\hline & \multicolumn{2}{|c|}{ INF } & \multicolumn{2}{|c|}{ INF $1^{\text {st }}$ lag } \\
\hline & Coefficient & $\mathrm{P}>[\mathrm{t}]$ & Coefficient & $\mathrm{P}>[\mathrm{t}]$ \\
\hline Constant & 9.623 & 0.060 & -78.978 & 0.000 \\
\hline PD_gdp & -.126 & 0.000 & -.103 & 0.031 \\
\hline TBO_gdp & .095 & 0.700 & -.019 & 0.958 \\
\hline CBO_gdp & -.181 & 0.075 & 2.341 & 0.000 \\
\hline CBI_gdp & .160 & 0.005 & 1.135 & 0.017 \\
\hline Observation & 90 & & 90 & \\
\hline R-squared (within) & 0.5465 & -- & -- & -- \\
\hline F-test & $F(6,46)$ & $\begin{array}{l}\text { Prob > F; } \\
\mathrm{P}=0.001\end{array}$ & -- & -- \\
\hline Durbin-Watson & -- & 2.131 & -- & -- \\
\hline Wald Chi 2 & -- & -- & $\begin{array}{l}\text { Wald chi2 } \\
547.32\end{array}$ & $\mathrm{P}>$ chi2 $=0.000$ \\
\hline \multicolumn{5}{|c|}{ Diagnostic Test for Cointegration - Pedroni Test } \\
\hline & \multicolumn{2}{|c|}{ Statistic } & \multicolumn{2}{|c|}{$p$-value } \\
\hline Modified Phillips-Perron $t$ & \multicolumn{2}{|l|}{1.9690} & \multicolumn{2}{|l|}{0.5245} \\
\hline Phillips-Perron $\mathrm{t}$ & \multicolumn{2}{|l|}{-1.4883} & \multicolumn{2}{|l|}{0.0083} \\
\hline Augmented Dickey-Fuller t & \multicolumn{2}{|l|}{-1.3740} & \multicolumn{2}{|l|}{0.0047} \\
\hline Sargan test & \multicolumn{2}{|l|}{28.079} & \multicolumn{2}{|l|}{0.3054} \\
\hline
\end{tabular}

Dependent variable: Inflation. Note. $\left({ }^{* *}\right),\left(^{* *}\right),\left(^{*}\right)$ significant respectively at 1,5 and 10 percent.

The econometric findings presented in Table 4, according to the FE and GMM model - Arellano-Bond public dept-to-GDP has a significant impact with negative signs on inflation for the panel countries surveyed. These substantiated arguments result in the fact that every increase per unit of PD_gdp will affect the reduction of the inflation rate by 1.26 units according to $\mathrm{FE}$, and 1.03 units according to GMM. Analyzing the countries of the Western Balkans (Durguti 2020) in their study the determinants that cause inflation, have empirically argued that budget deficit, public debt, and real exchange rate have an impact on inflation. Also, the study conducted recently in this perspective by Amiola and Odhiambo (2021) using the empirical ARDL bounds approach including the observation period 1983-2018. The results of this study are contradictory to the cointegration regression where it appears that public debt, in the long run, provides solid evidence between these two parameters, while the ARDL assessment in both short-term and long-term terms has shown insignificant evidence. These findings also present the inconsistency of agreement between researchers, as from the perspective of the approach, the form of application of the empirical approach, etc. Therefore, our results are consistent with the arguments presented by Durguti 
(2020). Government outflows have recently been the focus of discussions, especially in the Covid-19 period, when many economic entities suspended their activities as a result of measures to close or limit activities by order of the respective governments. Therefore, proactive and supportive governments in revitalizing the economy must channel those outflows that will affect economic growth, and at the same time keep inflation under control. The authors Attari and Javed (2013) using the ADF unit root test technique, ARDL, Granger Causality, and Johansen Cointegration test have argued that there is a long-term relationship between government spending and inflation. Despite the fact (Egbetunde and Fasanya 2014) including data for 1970 to 2010, they argued that overall government spending has a significant negative impact, while current spending has a significant impact on economic development. Therefore, the results of our study, in addition to verifying that they have a significant impact on inflation and that with a confidence level of 99.9 percent in both applied models. The results generated for this variable show that the FE approach has a negative impact, which is consistent with the results of (Egbetunde and Fasanya 2013), while according to the GMM assessment has a contradictory result with a significant positive impact and is consistent with the study by Attari and Javed (2013).

And the last parameter, but not in terms of importance is the capital budget investment wherein in both models there is a significant positive result against inflation with significance levels of 1 percent. According to $\mathrm{FE}$, the coefficient is 0.161 , respectively 1.135 according to GMM, which consequently determines that each rise for one unit of capital budget investment affects the rise for 0.16 units, respectively 1.135 units of inflation. Kryeziu and Durguti (2019) in their study of the impact of inflation on GDP growth for Eurozone states, applying several tests and multifactorial regression investigation have found that the rise in capital outflows has an important influence on inflation. Egbetunde and Fasanya (2014) reached the similar result that government investment in infrastructure, social matters, and additional financial activity should be increased. Therefore, based on these arguments, our study is in full accordance with these studies apostrophized on the one hand and with the expected results.

\section{Post-Diagnostic Estimations}

The findings of the post-diagnostic examination, the Pedroni co-integration examination, and the Sargan examination are revealed in Table 4 to advocate reliability. The co-integration check to be conducted must be on condition that the data is fixed at the level or in the first difference and our case that the data has been stationary at the first difference, and the results of the Pedroni examination confirm the fundamental assumption that the data are not being cointegrated, as the Phillips-Pedroni coefficient is $P=0.5245$ and the ADF examination with coefficient $P=0.0047$. 
Also, Hansen J-statistics of over-identifying restrictions, which are insignificant (see Table $4 \mathrm{P}=0.3054$ ) for the instrument validity.

Hypothesis Verification

The findings of the hypothesis confirmation or non-confirmation via econometric evaluation are shown in Table 5.

Table 4: Estimation Results (Source: Author's calculation)

\begin{tabular}{|l|l|c|c|c|}
\hline No. & \multicolumn{1}{|c|}{ Hypothesis } & Significance Level & $\begin{array}{c}\text { Confirmation of } \\
\text { Ho: }\end{array}$ & $\begin{array}{c}\text { Confirmation of } \\
\text { Ha: }\end{array}$ \\
\hline $\mathbf{1}$ & Public debt & $\mathrm{P}=0.000$ & Rejected & Accepted \\
\hline $\mathbf{2}$ & Overall government outflows & $\mathrm{P}=0.700$ & Rejected & Rejected \\
\hline $\mathbf{3}$ & Current government outflows & $\mathrm{P}=0.000$ & Accepted & Rejected \\
\hline $\mathbf{4}$ & Capital government outflows & $\mathrm{P}=0.017$ & Accepted & Rejected \\
\hline
\end{tabular}

Based on the preceding table, we can infer that three of them have been verified out of four premises examined. In the main hypothesis, two of them were verified, whereas one was confirmed in the alternative hypothesis with an importance of 1 percent.

\section{CONCLUSION}

The main purpose of this study was to analyze the relationship between some of the macroeconomic variables and the inflation rate for the SEE countries. In particular, we have investigated whether these variables impact inflation, applying these indicators public debt, overall government outflows, current government outflows, and capital government investment. To achieve the objectives, we have applied the dynamic approaches using the panel data for the countries specified in the analysis, including the periods 2006-2020, which in total are 90 observations. The exclusiveness of this study is that tests were applied for each applied model, to analyze how considerable the dependent variable is explained by the independent variables, tests on serial correlations, Pedroni test for co-integration, and Sargan test for over-identifying restrictions all of which have consistent results at a significance level of $1 \%$.

The findings of this study are under the expected results and following the studies conducted earlier by different researchers applying different approaches and models to achieve the most accurate results. The component, which has been analyzed by many authors is public debt, the confirmed results show us that any public debt in the SEE countries affects the increase in inflation. Moreover, current government outflows have an inverse influence on the inflation rate according to fixed-effect, and 
confident effect according to Arellano-Bond. However, the important component of macroeconomic determinants is capital government investment has a positive impact on the inflation rate. The surprise of this study is the variable overall government outflows and what impact it has on inflation based on the fact that a few studies have been conducted on this indicator, especially in the countries of the SEE countries and the European Union. The outputs of this indicator according to the econometric analysis are contradictory by applied models, where according to the fixed effect, there is an insignificant impact, and according to the GMM, we have an insignificant influence and inflation. The scope of this study was limited to the collection of other important data for macroeconomic indicators, as for some other important indicators we did not have the opportunity to provide data to enrich the study. These findings provide a clear path for future research on macroeconomic variables, moreover applying their subcomponents as well as the application of other dynamic models to study their effects in the short and long term. 


\section{REFERENCES}

1. Aimola, A. U., and N. M. Odhiambo. (2018). "A Review of Public and Private Debt Dynamics in Nigeria." Socio-economic - The Scientific Journal for Theory and Practice of Socio-Economic Development 7 (14): 1-18.

2. Akingbade U. Aimola \& Nicholas M. Odhiambo |Christian Nsiah (Reviewing editor) (2021) Public debt and inflation nexus in Nigeria: An ARDL bounds test approach, Cogent Economics \& Finance, 9:1, https://doi.org/10.1080/23322039.2021.1921905.

3. Baltagi, B. H. (2013). Econometric Analysis of Panel Data (5th Edition). Publisher: Wiley. New York.

4. Barro, R. J. (1974). Are Government Bonds Net Wealth? Journal of Political Economy, 82(6), 1095-1117. https://doi.org/10.1086/260266.

5. Barro, R. J. (1989). The Ricardian Approach to Budget Deficits. Journal of Economic Perspectives, 3(2), 37-54. https://doi.org/10.1257/jep.3.2.37.

6. Durguti, E. A. (2020). How Does the Budget Deficit Affect Inflation Rate - Evidence from

7. Western Balkans Countries. International Journal of Finance \&Amp; Banking Studies (2147-4486), 9(1), 01-10. https://doi.org/10.20525/ijfbs.v9i1.526.

8. Egbetunde, T. i O. Fasanya, I. (2014). Public Expenditure and Economic Growth in Nigeria: Evidence From Auto-Regressive Distributed Lag Specification. Zagreb International Review of Economics \& Business, 17 (2), 0-0. Preuzeto $s$ https://hrcak.srce.hr/129457.

9. Erdogdu, Oya Safinaz, (2002). "Price level determination: Ricardian vs nonRicardian policies ". Retrospective Theses and Dissertations.

511.https://lib.dr.iastate.edu/rtd/511.

10. Esat Durguti, Qazim Tmava, Filloreta Demiri-Kunoviku \& Enver Krasniqi, (2021) Panel estimating effects of macroeconomic determinants on inflation: Evidence of Western Balkan, Cogent Economics \& Finance, 9:1, https://doi.org/10.1080/23322039.2021.1942601.

11. Friedman, M. (1968). Dollars and deficits: Inflation, Monetary Policy and the Balance of Payments. Prentice-Hall, International.

12. Han, $\mathrm{H}$ and Mulligan, C. B., (2008). 'Inflation and the size of government', Federal Reserve Bank of St. Louis Review, 90(3, Part 2), (2008), 245-267.

13. J. Durbin \& G.S. Watson (1971), Testing for Serial Correlation in the least Squares Regression III. Biometrika 58, 1-19.

14. J. Racine \& R. Hyndman (2002), Using R To Teach Econometrics. Journal of Applied Econometrics 17, 175-189. 
15. Javid, A., Arif, U., \& Sattar, A. (2008). Testing the Fiscal Theory of Price Level in the Case of Pakistan. The Pakistan Development Review, 47(4), 763-778. Retrieved September 8, 2021, from http://www.jstor.org/stable/41261252.

16. K. M. Guei (2019) External Debt and Growth in Emerging Economies, International Economic Journal, 33:2, 236-251, https://doi.org/10.1080/10168737.2019.1590727.

17. Karakaplan, M. U. (2009). THE CONDITIONAL EFFECTS OF EXTERNAL DEBT ON INFLATION . Sosyal Ekonomik Araştırmalar Dergisi , 9 (17) , 203-217. Retrieved from https://dergipark.org.tr/en/pub/susead/issue/28418/302586.

18. Kryeziu, N., \& Durguti, E. A. (2019). The Impact of Inflation on Economic Growth: The Case of Eurozone. International Journal of Finance \&Amp; Banking Studies (2147-4486), 8(1), 01-09. https://doi.org/10.20525/ijfbs.v8i1.297.

19. Kwon, G., McFarlane, L., \& Robinson, W. (2006). Public Debt, Money Supply, and Inflation: A Cross-Country Study and its Application to Jamaica. International Monetary Fund Working Paper, WP/06/121. https://doi.org/10.5089/9781451863819.001.

20. Lopes Da Veiga, J., Ferreira-Lopes, A., \& Sequeira, T. (2016). Public Debt, Economic Growth, and Inflation in African Economies. South African Journal of Economics, 84 (2), 294-322. https://doi.org/10.1111/saje.12104.

21. Magaly Duarte Urquhart (2021) Public debt, inflation, and the Fiscal Theory of Price Level in emerging markets: the case of Paraguay, Macroeconomics and Finance in Emerging Market Economies, https://doi.org/10.1080/17520843.2021.1927128.

22. Muhammad Irfan Javaid Attari and Attiya Y. Javed. (2013). Inflation, Economic Growth and Government Expenditure of Pakistan. Procedia Economics and Finance, ISSN: 2212-5671, Volume (5), pages 58-67, https://doi.org/10.1016/S2212-5671(13)00010-5.

23. Naresh K. Malhotra, (2019). Marketing Research: An Applied Orientation, (What's New in Marketing) $7^{\text {th }}$ Edition, Kindle Edition. ISBN-13: 978-0134734842.

24. Nastansky, A., \& Strohe, H. G. (2015). Public Debt, Money and Consumer Prices: A Vector Error Correction Model for Germany. Statistische Diskussionsbeiträge 51, Universität Potsdam, Wirtschafts- und Sozialwissenschaftliche Fakultät.

25. Nguyen, V. B. (2015). The Relationship between Public Debt and Inflation in Developing Countries: Empirical Evidence Based on Difference Panel GMM. Asian Journal of Empirical Research, 5(11), 221-236.

26. Philip Hans Franses and Eva Janssens, (2018). Inflation in Africa, Journal of International Financial Markets, Institutions, and Money. volume 57, pages 261292, ISNN: 1042-4431. https://doi.org/10.1016/j.intfin.2018.09.005.

27. Robert J. Gordon. (2017). The Rise, and Fall of American Growth: The U.S. Standard of 
28. Living since the Civil War. Business History Review, 91(1), 169-173. https://doi.org/10.1017/S0007680517000629.

29. Romero, J. P. B., \& Marin, K. L. (2017). Inflation and Public Debt. Monetaria, V(1), 39-94.

30. Sims, C. A. (2016). Fiscal Policy, Monetary Policy, and Central Bank Independence. [Online]. Retrieved from: $\mathrm{CB}$ Ind.pdf (princeton.edu).

31. Sims, C. A. 2016. "Fiscal Policy, Monetary Policy, and Central Bank Independence." Accessed September 26, 2017.

32. Taghavi, M. (2000). Debt, Growth, and Inflation in Large European Economies: A Vector Autoregression Analysis. Journal of Evolutionary Economics, 10 (1-2), 159173. https://doi.org/10.1007/s001910050010.

33. Tai Dang Nguyen, (2019). Impact of Government Spending on inflation in Asian emerging economies: Evidence from India, China, and Indonesia. The Singapore Economic Review, Volume 64, No.05.

https://doi.org/10.1142/S0217590816500338. 